Case Report

\title{
A Case of Trichoepithelioma, Granular Cell Appearance Type in F344 Rat
}

\author{
Shinji Yamamoto, Shin-ichi Mikami, Seiki Yamakawa, and Hijiri Iwata \\ Biosafety Research Center, Foods, Drugs and Pesticides (AN-PYO Center)
}

\begin{abstract}
A case of spontaneous trichoepithelioma having a partial granular cell appearance, which was found in a 109week-old male F344Du/Crj rat, is described. Grossly, a white soft subcutaneous nodule approximately $16 \times 13 \mathrm{~mm}$ in diameter was found at the right axilla of the animal. Histologically, the tumor showed two structural patterns, one composed of eosinophilic granular cell nests and the other resembling trichoepithelioma composed of basal cells in ribbon or solid pattern nests occasionally with horny cysts or whorls. The cytoplasm of the granular cells was positively stained with PAS and was diastase-resistant. Trichoepithelioma components were strongly immunostained for keratin, but granular cells were weakly stained for keratin. None of the tumor cells were stained for S-100 protein, desmin, and vimentin. Ultrastructurally, the granular cell cytoplasm was filled with lysosome-like structures containing numerous electron-dense bodies. Many of the tumor cells had a prominant desmosome with attached tonofilament. These findings appeared to be essentially similar to those of the granular cell basal cell tumor in dogs and humans. However, the most appropriate diagnosis of this case may be "trichoepithelioma with granular cell appearance or trichoepithelioma, granular cell type", based on its characteristic histological features showing a differentiation to hair follicles. (J Toxicol Pathol 1997; 10: 111 113)

Key words : Trichoepithelioma, Granular cell tumor, Granular cell basal cell tumor, Rat
\end{abstract}

Granular cell basal cell tumor in rats has been reported only in a male Wister rat (Courtney et al. 1992) ${ }^{1}$ and a female F344 rat (Yoshitomi et al. 1994) ${ }^{2}$. These rats had a granular cell variant of basal cell tumors as previously reported in humans ${ }^{3,4}$ and dogs ${ }^{5}$. We report the third case of a rat with this kind of tumor, which was different from the granular cell basal cell tumor, by showing granular cell nests in the trichoepithelioma. This report describes the gross, light and electron microscopical features of a specific granular cell variant of trichoepithelioma in a F344 rat.

One 109-week-old male F344Du/Crj rat, which was used in a 2-year carcinogenicity study in the control group, developed a white soft nodule measuring approximately $16 \times$ $13 \mathrm{~mm}$ in size at the right axillar region. The nodule was fixed in neutral-buffered formalin, embedded in paraffin, sectioned ( 3 micron thick) and stained with hematoxilin and eosin (HE) or periodic acid-Schiff (PAS) with diastase digestion or Alcian blue ( $\mathrm{pH} 2.5$ ). In addition, immunohistochemical examinaions were performed by the labeled streptavidinbiotin method (DAKO kit) for keratin $(1: 80$, DAKO), vimentin $(1: 10, \mathrm{DAKO}), \mathrm{S}-100$ protein $(1: 200, \mathrm{DAKO})$, desmin $(1: 50, \mathrm{DAKO})$, and PCNA $(1: 10$, DAKO). For electron microscopy, formalin-fixed tissues of the tumor were embedded in a mixture of Epon 812 and Araldite, after fixation in $2 \%$ paraformaldehyde plus $2.5 \%$ glutaraldehyde followed by postfixing in $1 \%$ osmium tetroxide, stained with

山本慎二 三上真一 山川諴己 岩田 聖

Accepted for publication: February 24, 1997

Mailing address: Shinji Yamamoto, Biosafety Research Center, Foods, Drugs and Pesticides (AN-PYO Center), 528-2, Arahama, Shioshinden, Fukude-cho, Iwata-gun, Shizuoka 437-12, Japan.
4\% uranyl acetate and lead citrate, and were examined by transmission electron microscopy (Hitachi H-7000).

The tumor was composed of eosinophilic granular cell nests and the trichoepitherlioma-like growth arranged in lobules of varying sizes. The tumor was sharply circumscribed from the surrounding fibro-vascular connective tissue. The area of trichoepithloma was composed of basal cells in ribbon or solid patterns occasionally with horny cysts or whorls (Fig. 1-A). The area of granular cells was characterized by various numbers of intracytoplasmic fine, faintly eosinophilic granules (Fig. 1-B). Intracytoplasmic, eosinophilic, spherical globules were blended indistinctly into granular cell areas (Fig. 1-C). Pycnotic nuclei and individual cell necrosis were occasionally observed. A mitotic feature was infrequently observed in both components of the tumor. The cytoplasm of the granular cells was positively stained with PAS and was diastase-resistant. Trichoepithelioma-like components were stained strongly for keratin, but granular cells were weakly stained for keratin. None of the tumor cells were stained for S-100 protein, desmin or vimentin. PCNA positive cells were frequently seen in both components of the tumor (Table 1). Electronmicroscopically, the granular cell cytoplasm was filled with a lysosome-like structure containing numerous electron-dense bodies. A prominent desmosome with the attached tonofilamants was occasionally seen in the tumor cells. Eosinophil granules were found to contain numerous single membrane-bound autophagosomes with mitochondria and rough endoplasmic reticulum, electron microscopically (Fig. 2 ).

Granular cell tumor (GCT) is a diagnostic designation of the tumor with characteristic microscopic features that include the multilobular and sheet-like patterns of growth with well-demarcated polygonal cells containing abundant 
Table 1. Results of Special Stains and Immunohistochemical Examinations

\begin{tabular}{|c|c|c|}
\hline & Trichoepithelial component & Granular cell area \\
\hline \multicolumn{3}{|l|}{$=$ Special stains $=$} \\
\hline PAS & negative & granules; weakly positive \\
\hline PAS and Diastase & negative & granules ; resistant \\
\hline \multicolumn{3}{|c|}{$=$ Immunohistochemical stains $=$} \\
\hline Keratin & strongly positive & weakly positive \\
\hline Vimentin & negative & negative \\
\hline S-100 protein & negative & negative \\
\hline Desmin & negative & negative \\
\hline PCNA & frequently positive & frequently positive \\
\hline
\end{tabular}

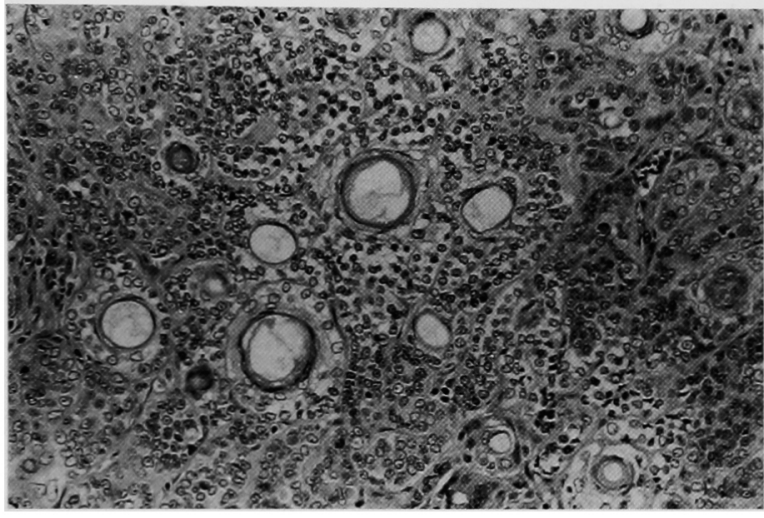

A

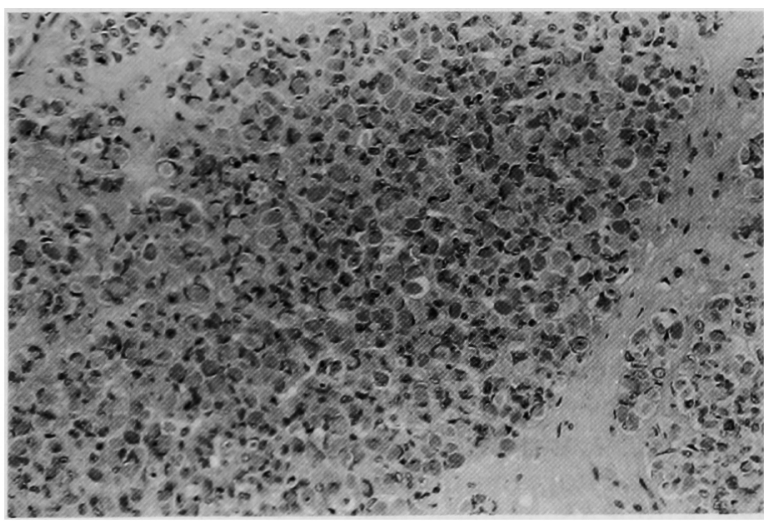

B

eosinophilic, periodic acid-Schiff (PAS)-positive, but diastase-resistan cytoplasmic granules. Granular cell tumors have been described in human beings, rats, dogs, horses, cats, and a bird? ${ }^{7}$ In human beings, GCT occurs most commonly in the skin and tongue but is sometimes seen in other soft tissue, including the central nervous system. Granular cell tumors in humans has been reported to be immunostained for S-100 protein and desmin, but weakly or not stained for keratin, suggesting on epithelial origin of the tumor cells. GCT is most commonly found in the meningeal tissue of the rat, and is most common in the tongue of the dog, although atypical locations have been also described in both species. The histogenesis of GCT in rats has been studied with

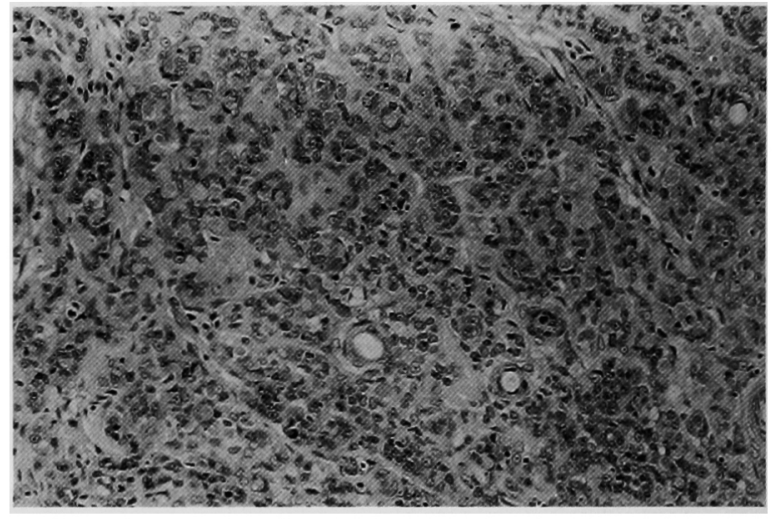

C

Fig. 1. A right axillar nodule showing two patterns of tumor cells.
A. Area of trichoepithelioma.
HE $\times 200$
B. Area of granular cells.
$\mathrm{HE} \times 200$
C. Area of co-existence of both cell types
$\mathrm{HE} \times 200$

electron microscopic and immunocytochemical techniques, and the neural-crest-derived primitive meningial arachinoid cell has been considered to be the cell of origin in these granular cell tumors ${ }^{6,10}$.

Basal cell tumors are known to have various histologic features because of their origin from pluripotential cells or embryonic primary epithelial germinal cells. Most basal cell tumors in rats show the differentiation toward the cutaneous appendages of hair and sebaceous glands. Granular cell basal cell tumors in rats and dogs or granular basal cell carcinoma in man are considered to be basal cell neolasms. However, the present case may be diagnosed as "trichoepithelioma with granular cell appearance or tricho- 


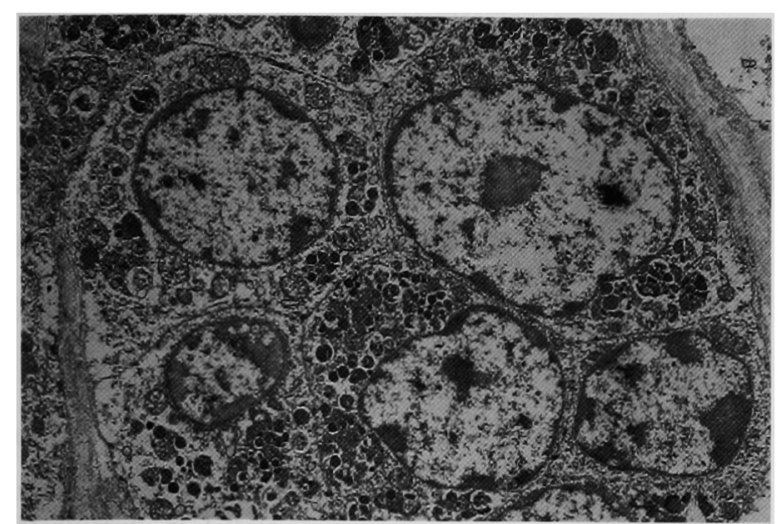

Fig. 2. Ultrastructure of granular cells.

Abundant cytoplasmic amorphous electron-dense materials are present. Granular cell rest on basement membrane.

epithelioma, granular cell type" based on the characteristic histological features showing the differentiation to hair follicles.

Acknowledgments : We would like to thank Dr. Makoto Enomoto for critical review of the manuscript and Mr. Ikuo Yamamoto for electron microscopic examination.

\section{References}

1. Courtney CI, Hawkins KL, and Graziano MJ. Granular basal cell tumor in a Wistar rat. Toxicol Pathol 1992; 20 : 122-24.

2. Yoshitomi $\mathrm{K}$ and Boorman GA. Granular cell basal cell tumor of the eyelid in an F344 rat. Vet Pathol $1994 ; 31$ : 106-8.

3. Barr RJ and Graham JH. Granular cell basal cell carcinoma. Arch Dermatol 1979; 115 : 1064-67.

4. Mark RE and Baker GF. Granular cell basal cell carcinoma. J Cutan Pathol 1987; 14: 37-42.

5. Seiler RJ. Granular basal cell tumors in the skin of three dogs. A distinct histopathologic entity. Vet Pathol 1981; 18: 23-29.

6. Mitsumori K, Dittrich KL, Stefanski S, Talley FA, and Maronpot RR. Immunohistochemical and electron microscopic study of meningieal granular cell tumors in rats. Vet Pathol 1987: 24: 356-59.

7. Patnaik AK. Histologic and immunohistochemical studies of granular cell tumors in seven dogs, three cats, one horse and one bird. Vet Pathol 1993; 30: 176-85.

8. Bounchard PR, Fortna $\mathrm{CH}$, Rowland $\mathrm{PH}$ and Lewis RM. An immunohistochemical study of three equine pulmonary granular cell tumors. Vet Pathol 1995; 32: 730-34.

9. Mazur MT, Shults JJ and Myers JL. Granular cell tumor -immunohistochemical analysis of 21 benign tumors and one malignant tumor. Arch Pathol Lab Med 1990 ; 114 : 692-96.

10. Wright JA, Goonetilleke UR, Waghe $M$, Stewart $M$, and Carlile A. Comparison of a human granular cell tumor (myoblastoma) with granular cell tumors (meningiomas) or the rat meninges an immunohistological and ultrastructural study. J Comp Pathol 1990; 103 : 191-98. 